\title{
Herakleitos'un Logos Felsefesi Bağlamında Panpsişizmin Arkeolojisi
}

\section{[The Archeology of Panpsychism within the Context of Heraclitus' Philosophy of Logos]}

\author{
İbrahim Körpe * \\ Akdeniz University
}

Received: 17.11.2021 / Accepted: 29.12.2021

DOI: 10.51404/metazihin.1024887

Research Article

\begin{abstract}
In this study, it is claimed that there are some close relationships between Heraclitus' views on logos and panpsychism's theory of mind, and that Heraclitus's understanding of logos is one of the teachings that establishes the foundations of panpsychism's theory of mind. Based on that, the paper emphasizes the meanings of "general rational principle, law or rule" and "rationality, ability to think" of the concept of logos. Regarding these meanings, it is pointed out that logos is closely related to the principle that "consciousness is fundamental," which is one of the basic characteristics of panpsychism. It is also pointed out that logos is the basic component, the element that is common to all things, especially the human mind. The paper aims to establish a close relationship between this idea and the idea that mentality, which is the second basic feature of panpsychism, is the basic quality that exists in all beings to certain degrees. In this study, it is also designated that the criticism of panpsychism that ignoring consciousness or mentality as a starting point in sciences is wrong, is related with Heraclitus' view that "knowing a lot is not wisdom." Accordingly, for Heraclitus, knowing logos without realizing it is not wisdom. In terms of panpsychism, too, the sciences are in a methodological error as they adopt the preacceptance that "what actually exists is physical" as a method at the starting point and ignore the consciousness and mentality "as the basic quality of nature."
\end{abstract}

Keywords: mind, logos, panpsychism, Heraclitus, fragments.

Öz: Bu çalışmada Herakleitos'un logos hakkındaki görüşleri ile panpsişizmin zihin kuramı arasında bazı yakın temaslar olduğu iddia edilerek Herakleitos'un logos anlayışının, panpsişizmin zihin kuramının temellerini kuran öğretilerden biri olduğu iddia edilmiştir. Buna göre ilk olarak logos kavramının “genel rasyonel ilke, yasa ya

\footnotetext{
* Author Info: Ph.D. Student - Akdeniz University, Faculty of Letters, Department of Philosophy, Konyaalt1Antalya, TURKEY.

E-mail: korpeibrahim@gmail.com / Orcid Id: https://orcid.org/0000-0003-0359-2200
}

To Cite This Paper: Körpe, İ. (2021). “Herakleitos'un Logos Felsefesi Bağlamında Panpsişizmin Arkeolojisi.” MetaZihin, 4(2): 91-110. 
da kural" ve "akılsallık, düşünme yetisi" anlamları üzerinde durulmuştur. Logosun bu anlamlar merkezinde panpsişizmin temel niteliklerinden bir tanesi olan "bilincin temel olduğu" ilkesiyle yakından ilişkili olduğuna değinilmiştir. Çalışmada ayrıca logosun insan zihni başta olmak üzere her şeyde ortak olan temel bileşen, unsur olduğuna değinilmiştir. Bu düşüncenin de panpsişizmin ikinci temel niteliği olan, zihinselliğin tüm varlıklarda belirli derecelerde var olan temel nitelik olduğu fikri ile yakın temasının kurulması hedeflenmiştir. Çalışmada ayrıca panpsişizmin bilimlerde başlangıç noktası itibariyle bilincin ya da zihinselliğin yok sayılmasının yanlış olduğu eleştirisinin, Herakleitos'un "çok şey bilmenin bilgelik olmadığı” görüşü ile yakın temas içinde olduğuna değinilmiştir. Buna göre Herakleitos açısından logosu idrak etmeden bilmek bilgelik değildir. Panpsişizm açısından da bilimler başlangıç noktasında metot olarak "gerçekte var olanın fiziksel olduğu" ön kabulünü benimsedikleri ve "doğanın temel niteliği olarak" bilinci ve zihinselliği yok saydıkları için yöntemsel bir yanlış içindedir.

Anahtar Kelimeler: zihin, logos, panpsişizm, Heraclitus, fragmanlar.

\section{Giriş: Logos'un Etimolojisi ve Anlamı}

Logos merkezli felsefesi ile Herakleitos, insan hayatının anlamına ilişkin tutarlı bir sistemi ileri süren ilk filozoftur (Arslan, 2016: 180). Onun logos hakkındaki görüşlerini, kendisinden kalan tek kaynak olan Fragmanlar' ${ }^{\prime}$ da görmekteyiz. Herakleitos'un felsefi görüşlerinin elde edildiği fragmanlar genellikle doğa, siyaset ve teolojiyle ilgili fragmanlar olarak üç gruba ayrılarak incelenir (Dürüşken, 2020: 97). Bu çalışmada, fragmanların bu üç grupta da merkezinde olan ve Herakleitos felsefesinin ana omurgasını oluşturan logos kavramı ile kavramın akılsallık [zihinsellik] şeklinde çevrilebilen anlamı üzerinden, panpsişizmin salık verdiği zihin öğretisi ile benzerliğine dair bir inceleme yapılacaktır. İncelemede logos kavramının, insanda ve tüm varlık alanında tezahürlerine dayalı akılsallığın [zihinselliğin] bütün var olanlarda içkin olması öğretisinden hareket edilecektir.

Öncelikle bahsetmek gerekir ki köken itibariyle Yunanca bir kelime olan logos, 'bir bütün oluşturan söz', 'cümle', 'tam söz', 'oran', 'düşünce', 'anlam' ve nihayet 'akıl' gibi anlamlara gelir (Arslan, 2016: 195). Logos kavramı Herakleitos'un fragmanlarında kullanımındaki kapsam genişliğinden dolayı birçok anlama gelmektedir. Bu anlamların neler olduğuna dair genel bir çerçeve çizmemiz gerekirse Herakleitos'un logos kavramını fragmanlarda üç temel anlamda kullandığını görmekteyiz: (1) Söz söyleme, anlatma ve söylem, akıl; (2) yasa, kural, ölçü, ilke ve miktar; (3) saygınlık ve ün (Çakmak, 2005: 30). Logosun Herakleitos'taki kullanımlarını incelerken özellikle

\footnotetext{
1 Bu çalışmada ana kaynak olarak Fragmanlar'ın Kabalcı Yayınları'ndan çıkan Cengiz Çakmak çevirisi kullanılmıştır. Ancak Türkçede var olan başka kaynaklara da dipnot olarak yer verilecektir. Fragmanlarda, köşeli parantez içindeki ifadeler çevirmene aittir.
} 
önem taşıdığını düşündüğümüz iki anlam üzerinde duracağız; "genel rasyonel ilke, yasa ya da kural" ve "akılsallık, düşünme yetisi" (Guthrie, 2011: 429).

Bu her zaman mevcut olan logosu insanlar yalnızca işitmeden önce değil, işittikten sonra da anlamiyorlar. Her şey bu logosa göre olup bittiği ve ben her şeyi doğasına göre ayırt ettiğim ve nasıl olduğunu bildirip açıkladığım halde, söylediklerimle ve yaptıklarımla karş̧laşıtıllarında acemi gibi davranıyorlar. Uykudayken ne yaptı̆̆ın unutan diğer insanlar gibi bunlar da uyanıkken ne yaptıklarını farkinda değiller. (Herakleitos, 2005: Fragman 29)²

Örneğin yukarıda alıntıladığımız ve diğer fragmanlara nispeten daha uzun olan ilk fragmanda logos, var olan her şeyin kural ve yasası olarak düşünülmektedir (Çakmak, 2005: 33). O, evrende egemen olan yasadır, düzen ve akıldır (Gökberk, 1998: 24). Bu anlamda kullanıldığında logos, bütün kozmosu ve içindekileri belirli kurallara göre düzenleyip yöneten bir tür kozmik bilinç ve düzenleyici ilke olarak yukarıdaki üçlü anlamdan ikincisi olarak karşımıza çıkmaktadır. Fragmana baktığımızda Herakleitos'un söze, kendi sözlerinde dillenen ve aynı zamanda kozmosta daima var olan logosu, insanların büyük çoğunluğunun anlamadığını belirterek başladığını görmekteyiz (Çakmak, 2005: 30). Ona göre insanlar kendilerine bahsedildiği, hakkında bilgi verildiği, anlatıldığı ve gösterilmeye çalışıldığı halde logosu anlamıorlar. Çünkü ona göre bu çoğunluk kendi dar ve sığ ilgileriyle uğraşıp durmaktan, gerçeğe ve hakikate kulaklarını tıkamış durumda olduklarından dolayı onu anlamamaktadır. Buradan anlaşılan, Herakleitos'un gerçeği, varlıkların özünü ve evrende olup biten şeylerin yapısını kendi söz ve tavırlarıyla açılayıp ortaya koymuş olmasına karşın insanların dinlemesini bilmediklerinden onun neyi kastettiğini anlayamamalarıdır (Çakmak, 2005: 31). Fragmanın son kısmında ise bir benzetme yapılmaktadır. Herakleitos, logosun farkında olmayan büyük çoğunluğun durumunun uykudaki insanların durumuna benzer olduğundan bahseder. $\mathrm{O}$, insanların büyük çoğunluğunun durumunu, insanların uyurken dünyadan ve dünyanın gerçekliğinden uzak kalmalarına benzetir çünkü uykuda herkes kendi öznel dünyasına döner (Akgün, 2016: 10). Bu benzetmede Herakleitos, uyuyan insanların hemen yanı başlarında gerçekliğin dinamik bir şekilde var olmasına rağmen onların hiçbir şekilde bunun farkında olmaması örneğini verir. Bu örnekle insanların büyük çoğunluğunun da

\footnotetext{
2 "Logos daima var olduğu halde, insanlar anlayışsız bir haldedir, hem işitmeden önce hem de ilk kez işittiklerinde. Çünkü her şey logos'a göre meydana geldiği halde, onlar bu türden sözleri ve işleri denemiş olsalar da, onun acemisi gibidirler; öyle ki ben her bir şeyi doğasına göre birbirinden ayırarak ve ne durumda olduğunu belirterek gözler önüne seriyorum. Tıpkı uyurken unuttukları gibi, başka insanlar da uyanıken yaptıkları şeyi göz ardı ediyorlar." (Herakleitos, 2019: 131). "İnsanlar her daim var olan bu logos'u işitmeden önce de, ilk defa işittikten sonra da kavramıyorlar. Her şey bu logos'a göre gerçekleşse de ben onların her birinin doğalarıyla uyumlu olduğunu analiz ederken ve nasıl olduklarını gösterirken bahsettiğim şeyleri ve sözlerimi anlamamış gibi davranıyorlar. Nasıl diğer insanlar uykudayken ne yaptıklarını hatırlamıyorsa, aynı şekilde bunlar da uyanıkken ne yaptıklarının farkında değiller." (Herakleitos, 2020: 9).
} 
hemen yanı başlarında, dünyada, varlıkta ve kendi içlerinde var olmasına rağmen logosun farkında olmadan yaşadıklarını vurgulamaktadır. Oysa Herakleitos açısından evrenin yasası olan logosu bilmek, tanımak aklın ödevidir (Gökberk, 1998: 25).

\section{Ana Hatlarıyla Panpsişizm ve Logos}

Panpsişizm terimi, 16. yüzyılda İtalyan filozof Francesco Patrizi tarafından literatüre kazandırılmış, "pan" (baştanbaşa, tümü) ve "psike" (zihin, ruh, can) sözcüklerinin birleşiminden meydana getirilmiştir (Onur, 2020: 73). Terimi oluşturan sözcüklerin anlamlarından da anlaşılacağı üzere panpsişizmin temel iddiası, zihinselliğin aslında her yerde, daha doğrusu varlığın her bir zerresinde içkin olduğudur (Arıcı, 2019: 142). $\mathrm{Bu}$ minvalde panpsişizmin iki temel iddialarından ilki, bilincin varlık sahnesine sonradan çıkmış bir fenomen değil, oluş sürecinin başından itibaren var olan bir fenomen olması anlamında bilincin temel olduğu iddiasıdır (Onur, 2020: 73). Bu iddia uyarınca bilinç, tıpkı doğadaki diğer temel fenomenler gibi sonradan oluşan bir şey değil doğanın genel düzeninde başlangıçtan bu yana var olan temel unsurlardan bir tanesidir. Panpsişizmin, ilkinin doğal bir sonucu olan ikinci temel iddiası ise bilincin tüm varlık skalasında belli biçim ve derecelerde bulunduğu şeklindeki iddiasıdır (Onur, 2020: 73). Bu görüşe göre insan varlığı ve hayvanlardan tutun da mikroorganizmalara, bitkilere ve cansız varlıklara kadar bütün var olanlarda belirli derecelerde zihin, daha da özelinde bilinç bulunmaktadır. Buna göre panpsişizm, evrendeki (fiziksel) her şeyin -her bir molekül, atom ve temel parçacığın- aynı zamanda bilinçli veya zihinsel bir bileşen içerdiğini ifade eden görüştür (Revonsuo, 2016: 81).

Panpsişizm, insan ruhu ve bilincinin analojiler kurma yoluyla doğadaki değişken varlıklara projekte edilmesi esasına dayalı animizmden farklıdır. "Animizm ve panpsişizm arasında maddenin "ölü" olmadığı noktasında bir görüş birliği olmakla beraber, panpsişizm maddeyi canlandırmak için ona tinsel ve şahsi ruhlar bahşetme yoluna gitmez." (Onur, 2020: 74). Bu noktada animizmden ayrılan panpsişizme göre bilincin ya da zihinselliğin tüm varlıklarda belli biçim ve derecelerde bulunması o varlıkların aynı zamanda canlı ya da antropomorfik olacakları anlamına gelmez. Panpsişizm ayrıca Antik Yunanların görüşlerinden biri olan, maddenin canlı ve hayat dolu olduğu esasına dayalı hilozoizme benzese de panpsişizm açısından canlılık ile bilinçlilik eşit olmadığı için bu iki görüş birbirinden ayrılır (Onur, 2020: 74).

Kolaylıkla fark edileceği üzere panpsişizmin zihin görüşü, zihnin fiziksel bileşenlerin karmaşık bir kompozisyonu sonucunda ortaya çıtığını ve aslında özü itibariyle fiziksel bir yapıda olduğunu iddia eden fizikalizmin görüşleriyle çelişir. Panpsişizm açısından fizikalizm iki açıdan kusurludur. İlk olarak burada "yokluktan varlık oluşmayacağına" (ex nihilo nihil fit) dair genel bir ilkenin, zihinsel olmayan bir şeyden zihinsel olanın 
çıabileceği iddiası ile ihlali söz konusudur (Mandik, 2014: 55). Buna göre zihnin, belirli fiziksel bileşenlerin çeşitli yollarla bir araya gelmesi, fiziksel bileşenlerin çeşitli oranlarda birleşimine dayalı bir kompozisyonun ürünü olduğu esasına dayalı olarak ortaya çıkan ve özü itibariyle fiziksel yapıda olduğunu savunan fizikalist iddialar, genel bir ilkeyi radikal bir biçimde ihlal etmektedir. Oysa yukarıda da bahsettiğimiz üzere, "yokluktan varlık oluşmaz" ilkesi gereğince hiçbir zihinsellik özelliği taşımayan fiziksel yapıtaşlarının bir araya gelerek sahip olmadıkları bir zihinselliği yoktan ürettikleri fikri mantıksal bir zorunluluk bildirmese de kabul edilebilir değildir (Arıcı, 2019: 143).

Panpsişizmin, fizikalizmin zihin görüşüne eleştirisi, zihnin doğasını açıklamak için yapılan sorgulamaların, başlangıçtan itibaren hatalı olduğuna yöneliktir. Buna göre zihnin ya da bilinçli deneyimin, zihinsel nitelikten yoksun olduğu varsayılan temel bileşenlerin sistemli bir kompozisyonu ile belirdiğini iddia edenlerin düştüğü temel hata, araştırmanın başlangıcındaki her şeyin fiziksel yapıda olduğu varsayımıdır (Heil, 2020: 264). Gerçekten de fizikalizmin bütün türlerinin, zihnin doğasını açıklarken ki çıkış noktası, zihni ya da bilinçli deneyimi ortaya çıkaran bileşenlerin tamamının özü itibariyle fiziksel olduğu varsayımıdır. İşte panpsişizme göre fizikalizmin en büyük açmazı da zihni ya da bilinçli deneyimi oluşturan temel bileşenlerin zihinsel nitelikten yoksun olduğuna dair asılsız bir varsayımla yola çıkmalarıdır (Heil, 2020: 264). Panpsişizm açısından bu varsayım hatalıdır. Çünkü zihin ya da bilinçli deneyimin ortaya çıkması ile çeşitli bileşenlerin bir araya getirildiğinde bilgisayarın ortaya çıkması benzer şeyler değildir. Başka bir deyişle taşları doğru şekilde dizerek bir katedrali nasıl oluşturacağınızı ya da molekülleri doğru şekilde bir araya getirerek bir sıvıyı nasıl elde edeceğinizi anlayabilirsiniz (Heil, 2020: 201). Ancak zihni ya da bilinçli deneyimlerin, kendileri bilinçli olmayan fiziksel ögelerin bir araya gelmesiyle oluştuğunu iddia etmek bu durumla aynı şey olmaktan çıkar. Dolayısıyla panpsişizme göre zihin ya da bilinçli deneyimin fizikalist ögelere indirgenmesine direnmesinin temelinde sadece fiziksel bileşenlerden oluşturulmamış olması vardır.

Bu noktada fizikalist cenahtan zihin ya da bilinçli deneyimlerin doğasının zaten fiziksel bileşenlerden oluştuğu, zihnin ve bilinçli deneyimin fiziksel ögelerden farklı yapıda olduğu varsayımının reddine dayalı bir karşı çıkış gelebilir. Ancak bu karşı çıkış hem yukarıda bahsi edilen "yokluktan varlık oluşmaz" ilkesi ile hem de bilinçli deneyimin indirgenmeye direnen zor bir yapıda olması ile karşılanır. Bilinçli deneyimin indirgenmeye direnen bir yapıda olması meselesini, Joseph Levine'in "açılayıcılık gediği" (the explanatory gap) diye adlandırdığı ve "fenomenal-fiziksel gedik" şeklinde ifade edebileceğimiz bir terim üzerinden ele alabiliriz (Arıc1, 2014: 3). 
"Açıklayıcılık gediği;" zihin ya da bilinçli deneyimin, duyusal algılamaların nörobiyolojik çözümlenmesinin felsefi sezgilerimizle çeliştiği iddiası etrafında merkezlenen bir açıklayıcı boşluktur. Bir örnek vermemiz gerekirse böğürtlenli bir dondurmayı yerken yaşadığım deneyimin tümüyle kendine özgü fenomenal nitelikleri bulunur ve bu nitelikler sadece benim deneyimlediğim, bana özel niteliklerdir (Arıc1, 2019: 115). Dondurmayı yediğimiz zaman beynimde oluşan nörobiyolojik patikalar fizikalizm tarafından kolaylıkla çözümlenebilir. Ancak önceki cümlede bahsettiğimiz böğürtlenli dondurmayı yiyor olmama dayalı bilinçli deneyim ve bu deneyimin farkındalığı, benzer fiziksel çözümlemelerle ortaya konulamaz. Benzer türden fiziksel çözümlemeler yapıldığında elde edeceğimiz şey, bilinçli deneyimin kendisi olmaktan çok bir takım sinirsel ve nöral aktiviteler ile duyular üzerinde bırakılmış etkilerin mekanizması olacaktır. Buna göre ne kadar fiziksel çözümleme yaparsak yapalım kahveyi içiyor olmama dayalı bilinçli deneyim ve deneyimin farkındalığ açıklanamayacak, bu durumun açıklamasını yaptığı düşünülen veriler de felsefi sezgilerimizi çiğneyen "açılayıcılık gediği" barındıracaktır. Bu durumda zihin ya da bilinçli deneyimler özü itibariyle fiziksel bileşenlerden oluşmayan bir yapıya sahiptir iddiasında bulunabiliriz. Eğer fiziksel bileşenlerden oluşmayan bir yapıdaysa da zihin ya da bilinçli deneyimlerin, fiziksel bileşenlerin örgütlü şekilde bir araya gelmesiyle ortaya çıkmaları da mümkün değildir. Çünkü biz biliyoruz ki uzaysal bütünler uzaysal parçaları gerektirir, o halde belki bilinçli bütünler de bilinçli parçaları gerektirir (Heil, 2020: 202). Bu durumda da mikro düzeyden makro düzeye kadar bütün var olanlarda zihinsellik olduğu iddiası etrafında merkezlenen panpsişizm fizikalizmden radikal bir şekilde ayrılır.

\section{Logos}

Logos kavramının Herakleitos'un fragmanları çerçevesindeki etimolojik analizi ile panpsişizmin zihin görüşü ve zihne yüklediği anlam arasındaki benzerlik oldukça çarpıcıdır. Şöyle ki logos hem insan varlıklarında hem de canlı-cansız bütün var olanlarda içkin şekilde var olan düzenleyici ilke, akılsallıktır [zihinselliktir]. Logos, gerçekten modern terimlerin önerdiğinden daha somut bir şeydir: Bütün insani düşünce ve zekâ her şeyi yöneten düşüncenin bir parçasıdır ve bu düşüncenin kendisinden ateş diye söz edilir; hareket eden, hep yaşayan ve bilinçli şey (Cornford, 2021: 145). Logos, insan düşüncesi ve zekâsı ile varlıklara içkinliğinden dolayı aşkın ya da ilahi bir şey değil içkin ve somut bir şeydir. Ancak buradaki somutluk, fiziksel bileşen olma anlamında bir somutluk olmaktan ziyade duyu-üstü bir somutluktur. Bu noktanın doğru şekilde anlaşılması Antikçă̆ Yunan felsefesindeki en temel meselelerin doğru şekilde anlaşılmasını sağlar. Özellikle Aristoteles'te ilk madde olan proto-hyle, mahiyeti belirsiz bir yapıda olması itibariyle bilinemez. Ancak evrendeki tüm cisimlerin bu ilk maddeden oluştuğu savlanır. Yani madde mahiyeti belirsiz bir unsur 
olmakla birlikte tüm cisimlerin maddi nedenini teşkil eder. Belirsiz mahiyeti ile madde tektir ancak fiziksel anlamda maddeden türeyen cisimler çeşitlilik arz eder. Benzer şekilde kozmik bir bilinç olarak logos da tektir ancak başta insandaki akılsallık, düşünce olmak üzere varlıklarda değişik derecelerde içkin bir çeşitlilikte vardır. Logos, insan düşüncesi ve zekâsı ile tüm diğer varlıklara içkin olmakla birlikte duyu-üstü bir somutluğa sahiptir diyebiliriz. Bu bağlamda düşündüğümüzde, Herakleitos açısından logos, şeylerin nesnel bir durumudur, her şeyde ve her insanda ortaktır (Guthrie, 2011: 434). İnsan, kendi düşüncesi ve zekâsı başta olmak üzere varlıklarda içkin olan bu gerçekliğe temas etmek için ne yapmalıdır? Herakleitos açısından bu gerçekliğin farkındalığına sezgi ve içgörüsel bir farkındalıkla erişilebilir. Logosu kavrayacak içgörüye sahipseniz onu dış doğada ele geçirebilirsiniz, logosun gerçekliği kişinin kendi içinde eksiksiz bir biçimde bulunur (Guthrie, 2011: 426). Nitekim Herakleitos, bu hususu şöyle ifade eder: "Kendimi keşfettim." (Herakleitos, 2005: 237. Fragman: 101)., ${ }^{3}$

\section{Keşif ve Farkındalık}

Herakleitos son derece kisa ancak bir o kadar da kendinden emin bu fragmanında kendisini keşfettiğinden bahseder. Keşif, belirli bir şeyin varlığının ortaya çıartılmasıdır. Peki Herakleitos kendisinde neyin varlı̆̆ını ortaya çıkarmıştır? Takip eden fragmanlarda bu sorunun cevabını bulmaktayız: "Bütün yolların yürüsen bile ruhun sinırlarına ulaşamazsın, öylesine derindir ruhun logosu." (Herakleitos, 2005: 119. Fragman: 45). ${ }^{5}$ Ruhun derin logosa sahip olması, kozmosa açılmasını ve kozmik logosla bağlantı kurmasını sağlar (Çakmak, 2005: 119). Burada söz konusu olan bir tür bilişsel farkındalıktır. Bu bilişsel farkındalık insanın kendisi üzerine yönelerek başta bilinci olmak üzere varlığının üzerine derinlemesine düşünmesi sonucunda edinilen bir tür kendilik bilincinin keşfidir. Bilincin ve benliğin derinliklerine inildikçe Herakleitos'un ruhun logosu diye ifade ettiği kendilik bilinci keşfedilmektedir. Bu noktada ruhun logosundan anladığımız, insanın benliğinin derinliklerinde bulunan ve keşfedilmeyi bekleyen, insanın asıl özü ve gerçekliği anlamına gelen temel bileşen yahut kendilik bilincinin [zihinselliğin] saf farkındalığıdır diyebiliriz. Herakleitos, kendimi keşfettim derken, evrendeki bütün varlıklara içkin olan logosun, kendi zihninin temelini kuran kendilik bilincinin varlığının farkındalığını edindiğini söyler. Ona göre bu keşifle edinilen farkındalık, başladığı andan itibaren oluşun ${ }^{6}$ doğası gereği olarak ve bireyin

\footnotetext{
3 “Kendimi aradım." (Herakleitos, 2020: 15). “Kendimi araştırdım.” (Herakleitos, 2019: 191).

${ }^{4}$ Gnothi s'auton, (kendini tanı) prensibi, Delphi Tapınağı'nın girişinde bulunan sözdür.

5 “Tüm yolların dolaşan yine de ulaşamaz ruhun sınırlarına. Öyle derindir onun logos'u" (Herakleitos, 2020: 23). "Bütün yolu kat etsen de ruhun sınırlarını bulamazsın; onda derin bir logos vardır." (Herakleitos, 2019: 159).

${ }^{6}$ Oluş, Herakleitos düşüncesindeki en merkezi kavramlardan bir tanesidir. Herakleitos evrendeki her şeyin sürekli hareket ve dinamizm halinde olduğunu söyler. O'na göre evrendeki hiçbir şeyde hiçbir şekilde bir
} 
kendi çabaları ile de kendisini sürekli çoğaltır: "Ruhun logosu kendisini çoğaltır." (Herakleitos, 2005: 267. Fragman: 115). ${ }^{7}$ Bireyin, kendi zihinselliğinde kendilik bilincinin saf farkındalığını kazandığı logosun artıp çoğalması ateşe yaklaştıkça parıldayan, 1şıldayan kömürlere benzetilebilir (Çakmak, 2005: 267). Buradaki benzetme ile hedeflenen, bireyin benliğinde ortaya çıkıp onu dönüştürecek kertede etkisi büyük olan farkındalığın mahiyetini ortaya koymaktır. Bu farkındalıkta farkına varılan ve Herakleitos'un ruhun logosu adını verdiği kendilik bilinci; kömür, Herakleitos'un evrendeki her varlıkta var olduğunu iddia ettiği kozmik logosta ateş olarak alınabilir. Benzetme üzerinden devam edecek olursak nasıl ki kömürler ateşe yaklaştıkça parıldayıp ışıldar ve tutuşursa ruh ya da kendilik bilinci de aynı şekilde kozmik logosa yaklaştıkça 1şıldar ve kendisindeki logosu ortaya çıkarır (Çakmak, 2005: 267). Bu noktada ruhun logosu Herakleitos'un bahsettiği keşiften önceki pozisyonda, durağan ve pasif iken keşifle edinilen farkındalık sayesinde kozmik logosla bağlantı erişimine kavuşarak harekete geçer ve aktifleşir. Buradaki bağlantı karanlık ve puslu bir ormana güneşin doğmasıyla birlikte karanlık ve sislerin yavaş yavaş ortadan kalkmasına benzetilebilir. Birey, kendisinde, kendilik bilinci olarak tezahür eden logosun farkındalığıyla birlikte kozmik logosla bağlantı olanağına erişir.

Özetle, ruhun logosunun keşfi ve bu keşifle edinilen farkındalık, bireyin hayatında köklü bir dönüşüm meydana getiren türden bir aydınlanma hali olarak görülebilir. Herakleitos'a göre logos, insanın kendi benliğinde farkındalığına ulaşması gereken en değerli şeydir. Onun açısından nadir bulunan şeyleri elde etmek zor ve zahmetlidir (Arslan, 2016: 184). Herakleitos bu durumu altın örneğini vererek ifade eder: "Altın arayanlar çok fazla toprak kazarlar ve çok az bulurlar." (Herakleitos, 2005: 73. Fragman: 22). ${ }^{8}$ O'na göre altın, hakikati ya da daha özel anlamda logosu simgeleyen ve derinlerde olup öyle kolaylıkla kendini ele vermeyen bir şeydir (Çakmak, 2005: 73). Bu bağlamda altın hem değerlidir hem de onu topraktan bulup çıkarması oldukça güçtür. Burada ifade edilmek istenen ana husus, hakikate ulaşmak için derinleşmek ve hakikatin üzerini örten önyargılardan kurtulmak gerektiğidir (Çakmak, 2005: 73). Çünkü Herakleitos açısından "Doğa saklanmayı sever." (Herakleitos, 2005: 283. Fragman: 123). ${ }^{9} \mathrm{Bu}$

\footnotetext{
durağanlık yoktur. Her şey her an bir değişim içerisinde akıp gitmektedir. Herakleitos'a göre dünya, sürekli olarak değişir, 'akış içindedir' ve görünüşteki istikrar kesinlikle bir yanılsamadır (Solomon, R.C. - Higgins, K.M. 2013: 55). Herakleitos'un her şeyin sürekli değişip dönüşmesi esasına dayanan panta rhei (her şey akar) öğretisi, Herakleitos felsefesinin en merkezi temalarından bir tanesi olmuştur.

7 “Ruhun logos'u kendini artırır.” (Herakleitos, 2020: 23). “Ruhun logos'u kendini çoğaltır.” (Herakleitos, 2019: 199).

8 "Altın arayanlar çok toprak kazar ama az altın bulur." (Herakleitos, 2020: 15). "Çünkü altın arayanlar toprağı çok kazarlar ancak az bulurlar." (Herakleitos, 2019: 145. Fragman: 22).

9 “Doğa saklanmayı sever." (Herakleitos, 2020: 14). “Herakleitos'a göre doğa gizlenmeyi sever.” (Herakleitos, 2019: 203).
} 
fragmanda doğa anlamında ele alınan physis sözcüğünün, şeylerin gerçek yapısı anlamına geldiği söylenebilir (Guthrie, 2011: 425). Başka bir deyişle nesnelerin doğası, esas yapısı, hakikati kendini doğrudan açmayan ve saklanmayı seven bir yapıdadır, bundan dolayı onu açığa çıkarmak zorlu bir iştir (Çakmak, 2005: 283). Bu da ciddi bir çaba ve sıkı bir çalışma gerektiren bir hedeftir. Herakleitos açısından bu hedef, çerçöpü bilgiye tercih eden sıradan insanlar için çok zor bir uğraştır (Çakmak, 2005: 73). Dolayısıyla logosun idraki yoluyla kendilik bilincinin, o saf bilincin farkındalığını edinmek adına bilinmesi gereken husus, bu girişimin ciddi bir çaba ve sıkı bir çalışma gerektiğidir.

Varlık felsefesindeki temel görüşlerden bir tanesi, başta kendi varlığımız olmak üzere bütün varlıklarda birbirine karşıt ögelerin birbirleriyle mutlak bir değişim içerisinde sürekli çatışarak bir uyum ortaya çıardığı fikridir. Herakleitos bu fikri şu şekilde ifade eder: "Karşıt olan şeyler bir araya gelir ve uzlaşmaz olanlardan en güzel uyum doğar. Her şey çatışma sonucunda meydana gelir." (Herakleitos, 2005: 45. Fragman: 8). ${ }^{10}$ Herakleitos'a göre karşıt olanlar, birbirleriyle uzlaşmaz olan ve farklı yönlere giden ögelere karşılık gelir (Çakmak, 2005: 45). Birbiriyle uzlaşmaz olan ve farklı yönlere giden ögeler, kozmosta sürekli işleyen değişim ve oluş ile birbirleriyle karşı karşıya gelir ve çatışır. Başka bir deyişle birbirine zıt olan ve birbiriyle uzlaşmaz görünen ögeler birbirini olumsuzlayarak sürekli çatışır ve her şey, farklı kuvvetler arasındaki zıtlık yasasına göre sürekli bir değişim halindedir (Skirberg, G. - Gilje, N. 2014: 29). Bu çatışmanın sonucunda da bir gerilim ortaya çıar. İşbu zıtların çatışmasından doğan gerilim düşüncesine göre, çatışma sonucunda bir uyum ortaya çıkar. Buna göre, görünüşte birbirine zıt olan şeyler, aslında bir ve aynıdır; bu birlik, daha derin düşünüldüğünde aynı zamanda uyumlu bir çokluktur (Dürüşken, 2020: 98).

Evrendeki varlıkların sürekliliği ve devamlılığını sağlayan şey bu çatışmadan doğan gerilim ve bu gerilim neticesinde ortaya çıkan uyumdur, Herakleitos'a göre uzlaşmaz ve birbirinden ayrı, birbirine zıt görünen ögeler bu çatışma sonucunda bir araya gelerek bir bağlam veya uyum oluşturur (Çakmak, 2005: 45). Bu uyumu sağlayan temel unsur ise, farklılıktaki gizli birlik olan ve evrendeki tüm varlıklarda içkin olarak bulunan zihinsellik olan logostur (Skirberg, G. - Gilje, N. 2014: 29). Buna göre Herakleitos'ta bağlam veya uyumu oluşturanlar, birbiriyle uyumlu olan ve uzlaşan ögeler değil, tersine uyumsuz ve uzlaşmaz olan ögeler ve bu ögeleri birbiriyle uzlaştıran rasyonel ilke olan logostur (Çakmak, 2005: 45).

10 "[Herakleitos' un söylediğine göre] karşıt olanlar bir araya gelir, en güzel uyum uyuşmaz olanlardan doğar ve her şey çatışmadan meydana gelir." (Herakleitos, 2020: 17). "Herakleitos, karşıt olanların bir araya geldiğini ve birbirinden ayrı olanlardan en güzel ahengin ortaya çıtığını söyler [her şey de çatışmaya göre meydana gelir]" (Herakleitos, 2019: 135). 
Herakleitos bu durumu yay ve lir örneğini vererek anlatır: "Uzlaşmaz şeylerin kendi aralarında nasıl uzlaştığını anlamazlar. Karşıt dönüşlerin uyumu; yay ve lirdeki gibi." (Herakleitos, 2005: 133. Fragman: 51).11 Bu düşünceye göre, kendinden farklı olan ya da kendinden ayrı düşen her şey zıtları oluşturur ama aynı zamanda zıt olanların birliği, bütünü oluşturur (Akgün, 2016: 61). Yayın yapısını, bir yanda içeri diğer yanda ise dışarı çeken, doğasını birbirine karşıt iki gücün birlikte çatışması meydana getirir (Çakmak, 2005: 133). Yay, birbirine karşıt ögelerin çatışması sonucu ortaya çıkan gerilim hattını ve bu gerilimden doğan uyumu sembolize eder. Bu bağlamda yay ve lir arasındaki tertium comparationis ${ }^{12}$ ahenk içinde çalışmak üzere birlikte gerilen iki karşıt gücün dinamikleridir (Jaeger, 2011: 165).

Herakleitos'a göre başta kendi varlı̆̆ımız olmak üzere doğadaki varlıkları izlediğimizde bu karşılıklı çatışma ve gerilimden doğan uyumu görmemiz mümkündür. Her şeyin sürekli değiştiği ve birbirini olumsuzladığı evrende çatışma ve gerilimlerden doğan birlikli uyumu görmek, logosun doğasını ve nasıl işlediğini anlamak için en önemli adımdır. Ona göre evren, zıtların mücadelesinin meydana getirdiği bir uyum ve armonidir (Arslan, 2016: 190). Bu uyum ve armoniyi sağlayan ve sürekli değişim içinde birbiriyle çatışan ögelerin aynı zamanda sabit bir şekilde var kalmalarını sağlayan ilke ise Herakleitos'a göre logostur. Logos, sürekli değişen ve birbiriyle çatışan ögeleri düzenleyip yöneten ve onların sabit bir şekilde var kalmalarını sağlayan temel düzenleyici ilke ya da kozmik zihindir. O'nun düşüncesine göre birbirine karşıt ögeler birbirine düzenli bağlanışlarla bağlanırlar ve birliktelik oluştururlar: "Bağlanışlar; bütünler ve bütün olmayanlar, bir arada duran ve ayrı duran, birlikte söylenen ve ayrı söylenen. Her şeyden bir, bir'den her şey." (Herakleitos, 2005: 49. Fragman: 10). ${ }^{13}$ Burada, birin kendisinden çokluğa dönüşebileceği ve yine de birliğini

11 "[İnsanlar] \{Bir'in] ayrışarak kendi içinde uyum sağladığını anlamıyorlar, [burada] tıpkı yay ve lirde olduğu gibi karşıtına dönüşme ve uyum [vardır]." (Herakleitos, 2020: 16). "Onlar ne bir şey biliyor ne de [bilmediklerini] kabul ediyorlar, \{Herakleitos onları\} şu şekilde suçluyor: Farklı olanın kendisiyle nasıl uyuştuğunu anlamıyorlar: Ondaki kendine-dönen bir ahenktir, tıpkı yay ve lirdeki gibi." (Herakleitos, 2019: 161).

12 Vech-i klyas

13 “Temaslar: Bütün olanlar ve bütün olmayanlar, bir araya gelen ve ayrılan, ahenkli olan olmayan, hem her şeyden Bir, hem Bir'den her şey." (Herakleitos, 2020: 16). "Aynı şekilde doğa karşıtlara ulaşmaya çabalar ve benzerlerden değil karşıtlardan bir uyum meydana getirir. Kuşkusuz tıpkı erkeğin dişiyle birleşmesi gibi, birleşme hemcinsler arasında değil karşıt cinsler arasında olur, ilk uyuşma karşıtlar aracılığıyla olmuştur, benzerler aracılığıyla değil. Benzer şekilde sanat da doğayı taklit ederek üretir. Çünkü resim sanatı beyaz ve siyah, sarı ve kırmızı renkleri karıştırdığında doğal nesnelerin asıllarıyla uyumlu suretlerini meydana getirir; müzik ise tiz ve pes sesleri uzun ve kısa sesleri karıştırarak farklı seslerden tek bir ahengi meydana getirir; dilbilgisi ise sesli ve sessiz harflerin karışımını yaparak kendilerinden çıkan bütün sanatı bir araya getirir. Bunlar böyledir ve 'Karanlık Herakleitos şöyle der: Bağlantılar: Bütün ve bütün olmayan, bir araya gelen ve ayrılan, birlikte söylenen ve ayrı söylenen, her şeyden bir ve birden her şey." (Herakleitos, 2019: 137. Fragman: 10).* 
koruyabileceğine dair bir inançla karşılaşırız (Cornford, 2020: 267- 268). Buna göre logos, bir taraftan şeylerin gerçek doğasında içkin olarak kendisini çeşitlendirip çoğaltmasına karşın diğer taraftan da birliğini ve kendi özsel yapısını korumaktadır. Herakleitos'a göre tek bir hakikat vardır ve bu hakikatin kaynağı olan logos, sizin içinizde ve etrafınızdaki her şeydedir (Cornford, 2020: 268). Filozof açısından tüm var olanlar özünde tüm kozmosun temel anlamı olan logosa belirli derecelere sahiptir. Yani tüm tikel şeyler bu bir anlamın, logosun simgeleridir; hiçbiri onun tam ve bağımsız bir ifadesi değildir (Cornford, 2020: 268). Cornford'dan alıntılanan bu son pasaj ile işaret edilmektedir ki logos her şeyde ortaktır ancak hiçbir şeyde tam ve bağımsız bir şekilde var değildir. Bir akılsallık [zihinsellik] olarak logosun tüm tikel şeylerde ve özellikle de insanlarda belirli derecelerde var olması ile panpsişizmin, zihinselliğin tüm varlıklarda belirli derecelerde var olması fikri arasındaki yakın temas ve benzerlik sadece bir tesadüf müdür? Herakleitos açısından logosu arayanlar, anlayarak açılmış gözlerle doğaya baksınlar, onu orada bulacaklardır; kendi doğalarına baksınlar, onu orada da bulacaklardır (Cornford, 2021: 148). Çünkü Herakleitos'un gözünde logos şeylerin nesnel bir durumudur, her şeyde ve her insanda ortak olarak vardır (Guthrie, 2011: 434). Her şeye nüfuz etmesi ve evrensel olması nedeniyle bu logos -evreni düzenleyen ve insan zihniyle kavranabilen bu yasa - her şeyde ortaktır (Guthrie, 2011: 436). Özetle Herakleitosçu keşif projesi, her şeyi yönlendiren düşünce olan logosun doğada olduğu gibi kendi içinde de keşfedilmesi gerektiği inancına dayanmaktadır (Cornford, 2021: 184). Bu görüş uyarınca denilebilir ki bizim zekâmız ilahi zekânın, logosun bir parçasıdır ve bu yüzden doğadaki varlıklarda içkin olup doğayı yöneten zekâyı ya da düşünceyi anlayabilme yeteneğimiz vardır (Cornford, 2021: 184).

\section{Başlangıçtaki Ortaklık ve Hep Orada Olanın Yok Sayılması}

Bir zihin kuramı olarak panpsişizme göre gerek insan varlıkları gerekse canlı cansız diğer bütün var olanlarda değişken derecelerde akılsallık veya zihinsellik vardır. Yani bir varlığı oluşturan fiziksel bileşenlerdeki karmaşıklık düzeyi arttıkça o varlığı oluşturan bileşenlerdeki zihinsellik düzeyi de buna paralel olarak artar. Bu kuram açısından insan zihninin gelişimi, fiziksel bileşenlerin bir kombinasyonu şeklinde bir gelişim olması ve bundan dolayı da basit zihinlerin daha karmaşık bir zihin yaratmak üzere birbirleriyle iç içe geçtiği bir yapı şeklinde açıklanabilir (Warburton, 2013: 141). Tıpkı bir paranın iki yüzü${ }^{14}$ gibi birbiriyle iç içe bulunan fiziksel ve zihinsel bileşenlerin, birbirleriyle birleşimine dayalı çeşitliliği ve karmaşıklık düzeyi arttıkça ortaya hem

\footnotetext{
* Fragman'dan ayrı olan metni ve fragmanın kendisini aktaran Aristoteles'tir.

${ }^{14} \mathrm{Bu}$ örnek zihin ile bedenin, tek bir tözün iki ayrı tezahürü olduğu iddiası etrafında merkezlenen çifte yön (double aspect) kuramından değil, zihin ile bedenin zihinsel ve fiziksel olmak üzere var oluş bakımından birbirinden bağımsız iki temel bileşenden oluştuğunu vurgulamak için verilmiştir.
} 
zihinsel hem de fiziksel gelişim açısından daha yetkin varlıklar çıkmaktadır. Örneğin çok az çeşitlilikte fiziksel bileşene sahip olan taşlarda ilkel düzeyde bir zihinsellik varken taşlardan daha çok fiziksel bileşene sahip olan bitkilerde taşlarınkinden daha ileri düzeyde bir zihinsellik vardır (Warburton, 2013: 141). Bundan dolayı bitkilerin, hayvanların, gezegenlerin, yıldızların ve galaksilerin hepsinin çeşitli derecelerde bilince sahip olduğu panpsişizm açısından dünya, bir zihinler ve ruhlar hiyerarşisinden oluşur (Revonsou, 2016: 81).

Panpsişizmin zihne dair bu görüşleri Herakleitos'un logosa yüklediği anlam ve işlevle birebir örtüşmektedir. Ona göre insana düşen temel görev, "her şeyin kendisine göre olup bittiği", "her şeyi yönetip düzenleyen" ve "bütün varlıklarda içkin bir şekilde var olan" logosun ne olduğunu anlamaya çalışmak ve önceki başlıkta değindiğimiz üzere keşfetmektir (Akgün, 2016: 83). Çünkü dünyada kendi yerimizi bulmak, yaşamayı öğrenmek ve eylemlerimizle dünyaya katkıda bulunmak için öncelikle bizi kuşatan dünyayı tanımalıyız (Ferry, 2018: 17-18). Bir önceki başlıkta da değindiğimiz üzere Herakleitosçu kendilik bilincini keşfetme projesi, evrendeki bütün varlıklarda içkin olan ve o ya da bu yolla tezahür eden rasyonel ilke, logosla [zihinsellikle] bağlantı kurmasını hedefler. Bu bağlantının kurulmasıyla birey, dünyada yalnız olmadığını anlayacak ve çokluğun ardındaki birlikle düzeni tecrübe edecektir. Çünkü Herakleitos'un da dediği gibi logos her şeye ortaktır: "Logos her şeye ortak olmasına karşın, çoğunluk sanki kendilerine özgü düşünceleri varmış gibi yaşar." (Herakleitos, 2005: 33. Fragman: 2). ${ }^{15}$

Bu bölümün başında alıntıladığımız fragmanda, her şeyin kural ve yasası olarak düşünülen logos, yukarıdaki fragmanda her şeye ortak, her şeyde bulunan bir unsur olarak değerlendirilir (Çakmak, 2005: 33). Özellikle bu fragman, panpsişizmin zihne dair görüşlerinin arkeolojik temellerini anlamak açısından oldukça önemlidir. Çünkü hem panpsişizm hem de Herakleitos akılsallığın [zihinselliğin] her şeye içkin ve her şeyde ortak olduğunu iddia etmektedir. Bu anlamda ele alındığında logos, bütün varlıklarda içkin olarak bulunan, varlıklardaki sürekli değişim ve çatışmadan etkilenmeyen rasyonel ilke ya da akılsallık [zihinsellik] olarak ele alınabilir. Benzer şekilde panpsişizm de fenomenal niteliklerin; bilincin, dünyanın temel özelliği olduğunu ve evrenin her tarafında bulunduğunu söyleyen bir kuramdır (Bailey, 2019: 358-359). Bu bağlamda sosyal topluluğun temeli olan insan aklı, kozmik topluluğun yani evrendeki tüm var olanların temeli olan evrensel aklın, logosun tezahürüdür (Hadot, 2012: 171). Herakleitos ortak olanın takip edilmesinden bahsederken şeylerin

\footnotetext{
15 "Ancak logos [her şeyde] ortak olmasına rağmen birçok insan kendi düşüncesi varmış gibi yaşar." (Herakleitos, 2020:9). "Bundan dolayı ortak olanı takip etmek gerekir; çünkü ortak olan geneldir. Logos genel olsa da çokları kendi düşünceleri varmış gibi yaşar." (Herakleitos, 2019: 131).
} 
ve haddizatında her şeyin temelinde bulunan bileşen olan düşünceyi, akılsallığ1 [zihinselliği] kastetmektedir (Akgün, 2016: 11).

Herakleitos'a göre derin bir logosa sahip olan insan, ruhundaki derin logosun farkındalığını edinmesiyle birlikte kozmosa açlarak kozmik logosla bağlantı olanağına kavuşur (Çakmak, 2005: 119). Burada bireyin kozmosa açılmasını mümkün kılan şey, kendi benliğindeki logosun, kendilik bilincinin keşfi ile farkındalığını edinmesidir. Bu farkındalıkla birlikte 'benzer benzeri çeker' prensibi gereği birey de kendisindeki logosun sayesinde kozmik logosla bağlantı olanağına kavuşur. Herakleitos'a göre mikrokozmos olan insan ile makrokozmos olan evren arasındaki ilişkinin temeli bu açılımda bulunur (Çakmak, 2005: 119). Panpsişizm açısından da sayısız bilinçli zihin tüm evrene nüfuz etmiştir, öznel iç yaşam her yanımızda akıp gider -insanlar, evrene yayılmış ucu bucağı olmayan bilinçsiz bir karanlıkta bulunan yalnız, soluk, bilinçsiz fenomenal 1şıklar değillerdir (Revonsou, 2016: 81). Başka bir deyişle zihin ya da zihinsellik sadece insana özgü olan bir yeti değil tam aksine tıpkı fiziksel bileşenler gibi tüm evrene nüfuz etmiş olan ve bütün varlıklarda içkin olarak var olan bir gerçekliktir. Panpsişizmin zihne dair bu görüşlerini Herakleitos'un yukarıdaki paragrafta incelediğimiz fragmanları ile düşündüğümüzde panpsişizmin zihin kuramının arkeolojisinde ciddi bir anlamsal benzerliğe temas ettiğimizi düşünmemizde bir sakınca yoktur.

Herakleitos'a göre, insanların büyük çoğunluğu gerçekliğin farkında değildir çünkü ona göre büyük çoğunluk dinlemeyi bilmiyorlar bu yüzden de onlar dildeki, benliğin derinlerindeki ve nesnelerdeki logosu anlamıyorlar (Çakmak, 2005: 67). Dolayısıyla da onlar, "Her zaman bir arada bulunduklarn şeyle, evreni yöneten logosla anlaşmazlığa düşüyorlar." (Herakleitos, 2005: 188. Fragman: 72). ${ }^{16}$ Bu fragmanda, doğal bir varlık olarak insanın başlangıçtan sona kadar her zaman logosla bir arada olduğuna, yani onun benliğinin derinlerinde onun kendilik bilincini yapılandıran temel unsurun logos olduğuna vurgu yapılmaktadır. Herakleitos'a göre insanların büyük çoğunluğu, logosun farkındalığını edinmediklerinden, her zaman onunla bir arada olduklarını fark etmeden yaşıyorlar. Dolayısıyla da evrendeki varlıkların temel tözsel bileşeni ya da düzenleyici rasyonel ilkesi olan kozmik logosa açılamıorlar.

Herakleitos'a göre yukarıdaki pasajda her zaman bir arada oldukları logostan habersiz yaşayanlar grubunda çok şey bilmenin bilgelik olduğu başlangıç noktasından hareket edenler de dahildir: “Çok şey öğrenmek anlayışlı [bilge] olmayı öğretmez, öğretseydi, Hesiodos

16 “Birçok insan ne kadar çok şeyle karşılaşırsa karşılaşsın, onların ne şekilde olduğuna kafa yormaz, onlarla ilgili bilgi sahibi olduktan sonra bile onları anlamaz, ama anladıklarını sanır." (Herakleitos, 2020: 9). "En çok, sürekli beraber oldukları bütünü yöneten logos'tan ayrılıyorlar ve her gün karşılaştıkları şeyler onlara yabancı görünüyor." (Herakleitos, 2019: 175). 
ile Pythagoras'a ve de Ksenophanes ile Hekataios'a öğretirdi." (Herakleitos, 2005: 109, Fragman: 40). ${ }^{17}$ Herakleitos açısından anlamadan, derinliğine araştırmadan çok şey bilmek veya öğrenmek, varlığın hakikatini anlama noktasında yetersiz kalır (Çakmak, 2005, 109). Çünkü bu yöntem başlangıç noktası açısından hatalıdır. Başlangıç noktasında, Hekataios ve Heredotos'un başını çektiği girişimler; bilinen dünyanın her yanını gezmek, her türlü insana sorular sormak ve olgusal bilgi toplamak ya da teoloji, ahlak, sanat, zanaat gibi konularda insanlara öğretmenlik yapmak veyahut felsefi anlamda Miletosluların yaptığı gibi dış doğayı incelemeye dayalıdır (Guthrie, 2011: 424). Herakleitos, tüm bu yöntemler sonucunda elde edilen bilgi yığınlarının hakikatin bilgeliğini doğurmayacağını söyler. Çünkü ona göre sadece çok şey bilmeye dayalı girişimler başlangıç noktası açısından eksik oldukları için kuru bir talimden öteye geçemeyecektir. Onun bilgelik yolundaki öğretisi ise önceki pasajlarda üzerinde durduğumuz, logosun farkındalığına dayalı kendilik bilincinin keşfi ve bununla beraber bireyin kozmik logosla bağlantı olanağına kavuşması yoluyla gerçekleşir. Ona göre hakikate dayalı bilgeliği elde etme ülküsü taşıyan bir araştırmacı talime girişeceği disiplin her ne olursa olsun başlangıçta, disiplinin talim içeriğinin yanında logosun farkındalığına da sahip olmalı yani Herakleitos'un tabiri ile "kendini keşfetmelidir".

Panpsişizme göre de insan zihnine dair yapılan araştırmalar, önceki ana başlıkta da değindiğimiz üzere başlangıç noktası açısından eksiktir. Buna göre zihnin ya da bilinçli deneyimin doğasına yönelik araştırmalardaki temel eksiklik, zihni ya da bilinçli deneyimi oluşturan temel bileşenlerin zihinsel nitelikten yoksun olduğuna dair asılsız bir varsayımla yola çıkılmasıdır (Heil, 2020: 264). Bu hususun doğru şekilde anlaşılması önemlidir. Panpsişizm başlangıç noktasında zihnin ya da zihinselliğin, özü gereği fiziksel olmayan ve bir yapıcı ya da oluşturucu öge olarak fiziksel bileşenlerden ayrı tutulması gereken bir nitelik olarak ele alınması gerektiğini iddia eder. Başka bir deyişle panpsişizm, zihnin ve bilinçli deneyimin açıklanması hususunda, temel şeylerin bilinçli niteliklerden, farkındalıktan yoksun olduğu varsayımını reddederek yola çıkar. (Heil, 2020: 265). Herakleitos'un önceki paragrafta incelediğimiz fragmanları ile panpsişizmin bu görüşü arasında yine ciddi bir anlamsal benzerlik olduğunu söyleyebiliriz. Şöyle ki Herakleitos'a göre logos, tüm varlıklarda 'her zaman' içkin bir şekilde akılsallık [zihinsellik] olarak var olan temel bileşendir. Panpsişizm açısından da zihinsellik tüm varlıklarda her zaman var olan ve fiziksel bileşenlerle birlikte ele alınması gereken temel bileşendir. Ayrıca Herakleitos'un, çok şey bilmenin bilgelik olmadığına dair fragmanı ve kendi döneminde yaşamış olan kimi muteber otoritelere ${ }^{18}$ yönelttiği

17 “Çok şey bilmek kavramayı öğretmez. Öyle olsaydı Hesiodos ile Pythagoras'a ve yine Ksenophanes ile Hekataios'a öğretirdi." (Herakleitos, 2020: 12). "Çok şey öğrenmiş olma akıllı olmayı öğretmez; çünkü öyle olsa Hesiodos'a, Pythagoras'a ayrıca Ksenophanes'e ve Hekataios'a öğretirdi." (Herakleitos, 2019: 155).

${ }^{18}$ Author probabilis 
eleştiriden anlaşılan temel husus şudur: Bilgelik araştırmasında üzerinde inceleme yapılan alan her ne olursa olsun, araştırmacı başlangıç noktasında şu iki hususu dikkate almalıdır: (1) Araştırma yapılacak disiplinin talim içeriği ve (2) logosun farkındalığına dair kendilik bilincinin edinilmesi yani bireyin "düşüncelerini kendi içine çevirerek gerçek benliğini -kaynağında logos olan gerçek benliğini- keşfetmesi (Guthrie, 2011: 426). Panpsişizm de yukarıda bahsettiğimiz üzere, zihnin doğasına yönelik araştırmalar başlangıçta gerçekten var olanın fiziksel bileşenler olduğu metodolojisi başlangıç noktası açısından eksik olduğunu zihnin fiziksel gerçeklik gibi var sayılması gereken bir temel nitelik olduğunu iddia eder. Herakleitos'un logosa yüklediği anlam ve işlev ile panpsişizmin zihne yüklediği anlam ve işlev birbirine bu denli yakın temas ettiği için panpsişizmin zihin görüşünün arkeolojik temellerinin Herakleitos'un logos ile ilgili düşüncelerinde olduğunu iddia etmek yerindedir.

Panpsişizm, zihnin doğasına dair görüşlerinin bilimle çelişen bir tarafının olmadığını da iddia eder. Çünkü panpsişizm açısından fiziksel olanın doğası itibarıyla bilince benzediğini veya ondan tümüyle farklı bir şey olduğunu iddia etmek için herhangi bir bilimsel dayanağa sahip değilizdir (Revonsou, 2016: 82). Hal böyleyken zihnin ya da zihinselliğin, zihne dair araştırmalarda yok sayılması ya da onun belirli bir fiziksel karmaşıklık düzeyi sonrasında beliren bir şey olduğunu savunmanın herhangi bir bilimsel dayanağı yoktur. Fiziksel anlamda fiziksel bileşenlere dair bildiklerimizin, zihnin doğasının fiziksel bileşenlerin karmaşık örgütlenmesi ile beliriveren bir şey olduğu sonucuna götürecek bir delilden yoksundur. Çünkü fiziksel olanın ne olduğunu bilmiyoruz, fakat bilincin temel iç doğasının ne olduğunu mutlak bir kesinlikle biliyoruz: niteliksel öznel deneyim (qualia) (Revonsou, 2016: 82). Gerçekten de niteliksel öznel deneyimlerimizin tam olarak ne ve nasıl olduğuna dair bilgilerimizin kesinliği, fiziksel olanın tam olarak ne ve nasıl olduğuna dair bilgilerimizin kesinliğinden fazladır. Hal böyle iken doğasına dair daha az bilgi sahibi olunan bir şey ile doğasına dair daha çok bilgi sahibi olunan bir şeyi açılamaya dayalı bir metodoloji ne kadar doğru olabilir? Ayrıca bu noktada panpsişizm fizikalist teoriler kadar radikal indirgemeler de yapmaz. Panpsişizm, zihni ya da bilinçli deneyimi açıklarken hem fiziksel hem de zihinsel ögelerin ontolojilerinin var sayılmasını salık verir. Bu iddiasını da fiziksel olanın aynı zamanda öznel niteliksel deneyime (qualia) karşılık gelecek bir iç doğasının veya boyutunun bulunabileceği iddiasıyla destekler (Revonsou, 2016: 82).

\section{Sonuç: Temaslar}

Herakleitos'un bir önceki paragrafta değindiğimiz fragmanıla panpsişizmin zihne dair son bahsettiğimiz görüşleri arasındaki benzerlik çarpıcıdır. Herakleitos'ta her şeye içkin olan, her şeyi yönetip düzenleyen akılsallık ile, logos [zihinsellik], bütün varlıklarda başlangıçtan itibaren içkin bir şekilde mevcut iken, panpsişizmde de 
zihinsellik, fiziksel bileşenlerin belirli bir karmaşıklık düzeyine erişmesi sonucunda beliren bir şey değil tam aksine fiziksel bileşenlerle birlikte başlangıçtan bu yana daima var olan temel ve özü itibariyle fiziksel olamayan bir unsurdur. Herakleitos açısından bütün varlıklarda başlangıçtan bu yana içkin bir şekilde var olan akılsallık ya da logosun [zihinselliğin] özü, bitip tükenmeyen bir hareketlilik ve oluş ile çatışmakta olan karşıtların ahenkli uyumu ve birlikli yapısıdır (Dürüşken, 2020: 102).

Herakleitos'a göre logos her yerde mevcut olmasına karşın insanlar onu anlamıyorlar (Çakmak, 2005: 97). Çünkü ona göre logosu anlamak için gerekli olan bilişsel ve duygusal donanım bütünlügünden ve derin bilgelikten yoksunlar. Bu noktayı biraz açacak olursak Herakleitos'un bilgelikten anladı ̆̆ şeyin ne olduğu üzerinde durmamız gereklidir. Herakleitos'a göre, "Bilgelik tektir; her şeyi her şeyle yöneten düşünceyi bilmektir." (Herakleitos, 2005: 111. Fragman: 41). ${ }^{19}$ Bilgelik, başta insanın kendi varlı̆̆ olmak üzere evrendeki bütün varlıkların düzenleyici temel rasyonel ilkesi olan kozmik aklı, logosu bilmektir. Dolayısıyla Herakleitos'a göre bilge olmak (sophon), çok şey bilmek değil, kozmostaki planı, düşünceyi, başka bir deyişle hakikati bilmektir (Çakmak, 2005: 111). Hakikati bilmenin anahtar noktası ise önceki başlıkta değindiğimiz husus olan çokluktaki birliği kavramak ve anlamaktan geçmektedir. Bu da kişinin önce kendi varlığının derinlerinde var olan logosun farkındalığı ile kendilik bilincini edinmesi ve böylelikle kozmik logosla bağlantı kurması yoluyla çokluktaki birliğin bilincine varması şeklinde gerçekleşir. Böylelikle logos, işitilecektir: "Beni değil logosu işiterek her şeyin bir olduğunu kabul etmek bilgeliktir." (Herakleitos, 2005: 131. Fragman: 50). ${ }^{20}$ Herakleitos, kendisine değil, logosa kulak vermelerini söylediği zaman, logosun kendi söylevinden daha fazla anlama geldiğinin açık olduğunu belirtmektedir (Cornford, 2021: 144). Bu anlayışa göre bilgelik, evrendeki varlıklar arasında var olan birlik ve bütünlüğü görmek ve bu birlikle bütünlüğün sağlayıcısı olan logosu işitmek demektir. Logosun işitilmesi de yukarıda bahsettiğimiz farkındalıkların edinilmesi ile mümkündür. Herakleitos'u işiten, logosu işitmiş demektir. Çünkü logos, söylemin dile getirdiği bir doğru yani daha çok, olup biten her şeyi yöneten gerçeklik olarak süren "hakikat" anlamina gelmektedir (Cornford, 2021: 144).

Başka bir deyişle Herakleitos, alıntıladığımız bu son fragmanda logosu hem söz hem de sözün yaslandığı hakikat ya da anlam olarak kullanmıştır (Çakmak, 2005: 131). Bu anlayış açısından hakikat, evreni ve evrendeki varlıkları düzenleyip yöneten rasyonel

19 "Bilgelik tektir: Her şeyi her şey üzerinden yöneten düşünceyi bilmek.” (Herakleitos, 2020: 15). "Çünkü bilgelik Bir' dir, her şeye her şey aracılığıyla yön veren düşünceyi bilmektir." (Herakleitos, 2019: 157. Fragman: 41).

20 "Asıl bilgece olan beni değil, logos'u dinledikten sonra her şeyin Bir olduğunu anlamaktır." (Herakleitos, 2020: 16). "Bana değil ancak logos'a kulak verenler için her şeyin bir olduğunda hemfikir olmak bilge bir şeydir." (Herakleitos, 2019: 161). 
ilke, logosa [zihinselliğe] kulak vermek ve onu işitmektir. Herakleitos kendisini logosun farkındalığını kazanıp kendilik bilincini keşfeden birisi olarak düşündüğünden sözlerinin de bu bağlamda ele alınmasını ima etmektedir: $\mathrm{O}$ bilgeliği "kendisini araştırarak" bulmuştur ama öte yandan bu bilgelik Herakleitos'un özel görüşleri değil, aksine "herkes için ortak olan bir şeydir." (Cornford, 2021: 147). Bu açıdan Herakleitos'un kendisi bilgedir; hakikati görmüş ve onu kendi logosunda yeniden üretmiştir (Cornford, 2021: 148). O'na göre bilgelik çok şey bilmek değil, logosu bilmek, fark etmek, yaşamak ve işitmektir. Kendisinin bu son fragmanda bir noktada logosun farkındalığıyla keşfini gerçekleştiren birisi olarak sözlerinin, logos'un 'söz' şeklinde tezahür eden hali olarak ele alınmasını salık verdiğini düşünebiliriz. Bu minvalde Herakleitos kendi sözlerinin ezeli ve ebedi hakikati yani logos'u dile getirdiğini ima etmektedir (Çakmak, 2005: 219). Bu durumda Herakleitos'un sözlerini Herakleitos söylemişçesine ele alıp değerlendirmekten ziyade onları logos'un söz şeklinde tezahür eden temsilleri olarak ele almak gerekmektedir. Böylelikle Herakleitos'a ve onun sözlerine kulak vermek, logos'un söz olarak tezahür etmiş haline yani hakikate kulak vermekle eşitlenir. Hakikate kulak verilip logos işitildiğinde insan, kozmostaki birlik ve bütünlüğü fark edecek ve böylelikle bilgelikle sonuçlanan bir aydınlanma ile aydınlanacaktır. Bu proje açısından bilgelik, ruhun dinginliğini (ataraxia), içsel özgürlüğünü (autarkeia) ve kozmik bilinci beraberinde getiren bir yaşam şeklidir (Hadot, 2012: 245). Bu aydınlanma projesinde bilge olan kozmosun bütünlüğüdür, bilgelik ise bu birlik ve bütünlügü kavramaktır (Çakmak, 2005: 253). Birlik ve bütünlüğün kavranması ise logos'un yani evrendeki tüm varlıklara içkin olan aklın [zihinselliğin] farkındalığıyla, bireyin kozmik aklın bilgeliği ile aydınlanması anlamına gelir. "Akla uygun konuşmak isteyenler, yasasına bağlı bir kentten daha güçlü bir şekilde her şeyde ortak olana sıkıca sarılmalıdır. Çünkü bütün insan yasaları tanrısal olandan beslenir. Bu tanrısal yasa her şeyi dilediğince yönetir ve her şeye fazlasıyla yeter." (Herakleitos, 2005: 265. Fragman: 114).21 Herakleitos açısından her şeyde ortak olanın logos olduğu bahsine yukarıda değinmiştik. Bu fragmanda bahsedilen husus, her şeyde ortak olan temel rasyonel ilke olan logos'a göre bir yaşam sürmenin toplumsal yaşam için oldukça hayati bir önemde olduğu fikridir. Çünkü Herakleitosçu proje açısından, toplumsal yaşamı düzenleyen unsurlar olan ve insanların oluşturdukları yasalar, insan aklının ürünü olan şeyler oldukları ve insan aklı da tanrısal akıl olan logos'un bir tezahürü olduğu, ondan beslendiği için aynı zamanda tanrısal olandan beslenir. Evrendeki temel düzenleyici rasyonel ilke olarak ele alındığında logos, devleti oluşturan bireylerin bağlı

\footnotetext{
21 "Aklıyla konuşanlar her şeyde ortak olana dayanmalı, tıpkı bir kentin kendi yasasına dayanması gibi, ama bunu [bir kentten] daha güçlü bir şekilde yapmalı. Zira insan yasaları bir yasadan, yani kutsal yasadan beslenir, dilediği gibi yönetir ve her şeye yeter, geriye fazlası kalır." (Herakleitos, 2020: 24). "Akıllarıyla söz söyleyenler yasalara uyan bir kent-devletinde olduğu gibi herkesin ortak yararını güçlendirmelidir ve daha da güçlü hale getirmelidir. Çünkü bütün insani yasalar tek bir yasadan beslenir; çünkü bu tanrısal yasa istediği gibi üstün gelir, her şeye yeter ve her şeyin üstesinden gelir." (Herakleitos, 2019: 199).
} 
bulunduğu yasalara benzese de, en kudretli devletlerin yasalarından bile büyük ve üstündür (Jaeger, 2011: 161). Çünkü, “düşünme herkese ortaktır. “(Herakleitos, 2005: 113. Fragman:113). Düşünme herkese ortak olduğuna yani evreni ve içindeki her şeyi yönetip düzenleyen temel rasyonel ilke olan logos herkese ortak olduğuna göre akla uygun bir şekilde konuşmak isteyenler her şeyde belirli ölçü ve oranlarda ortak olana, logos'a sıkıca sarılmalıdır (Çakmak, 2005: 265). Bu minvalde Herakleitos, sadece hakikati, logos'u bilmek istemekle kalmayan, bu bilginin insan hayatına etki ederek onu şekillendirip dönüştürecek bir husus olduğuna dikkat çeken ilk filozoftur (Jaeger, 2011: 159). Ona göre logos'u tanıyıp öğrenen kimse, doğadaki bu akıl yasasını kendi eylemlerine ve yasalarına kılavuz olarak alacaktır, böylece bu kimse 'genel'e bağlanmış olacaktır (Gökberk, 1998: 25). Onun istediği ve toplumda gerçekleşmesini arzuladı̆̆ şey, insanların tamamen uyanık ve kendinde ve her şeyin kendisine bağlı bir şekilde meydana geldiği logos'un bilincine vararak yasa kurmalarını, toplumu inşa etmelerini ve böylece aklın ışığı altında aydınlanmış bir yaşam sürmelerini sağlamaktır (Jaeger, 2011: 159).

Bilinçli öznelerin varlığını layıkıyla onaylayıp teslim edebilecek biricik metafiziğin kendi zihin kuramı olduğunu iddia eden panpsişizme göre de zihinsellik her şeyde mevcuttur (Priest, 2012: 118). Herakleitos'un anlayışına göre nasıl ki akılsallık [zihinsellik] ve her şeyi yönetip düzenleyen rasyonel bir ilke olarak logos bütün varlıklardan yasalara kadar her şeyde mevcut ise panpsişizmde de zihinsellik bütün var olanlarda benzer şekilde mevcuttur. Buna göre panpsişizm temel nitelikleri açısından cansız fiziksel varlıklardan canlı organizmalara kadar her şeyde içkin bir şekilde var olan zihinsellik, bireysel insan bilincinin üstünde insan türünün tamamının ortak bilinci, onun üstünde dünya gezegeninin bütün biyosferinin birleşik bilinci, daha üstte güneş sisteminin, galaksinin bilinci ve nihayetinde mutlak evrensel bilinç olarak vardır (Revonsou, 2016: 81).

\section{Kaynakça}

Arıc1, M. (2019). “Zihin Felsefesi: Ben Nerede, Zihin Bedensiz Var Olabilir mi?" Murat Arıcı (Der.), Felsefeye Giriş: Temel Problemlere Sistematik Yaklaşım içinde (s. 107152). Ankara: Nobel Yayıncilı.

Arıcı, M. (2014). “Materyalizm, Fenomenal Özne ve Ontolojik Statüsü." Beytül Hikme Felsefe Dergisi, 4(2): 01-13. Alındığı URL: http://www.beytulhikme.org/DergiTamDetay.aspx?ID=152\&Detay=Ozet

Arslan, A. (2016). İlkçă̆ Felsefe Tarihi: Sokrates Öncesi Yunan Felsefesi. İstanbul: Bilgi Üniversitesi Yayınları. 
Bailey, A. (2019). “Dipnot: Zihin Felsefesi-Önümüzdeki On Y1l.” Andrew Bailey (Der.), Zihin Felsefesi içinde (s. 351-363). Çev. Füsun Doruker. Ankara: Fol Yayınları.

Cevizci, A. (2012). Felsefe Tarihi. İstanbul: Say Yayınları.

Cornford, F. M. (2020). Dinden Felsefeye. Çev. Özgüç Orhan. İstanbul: Albaraka Yayınları.

Cornford, F. M. (2021). Bilgeliğin Başlangııı. Çev. Şahin Filiz, Fatih Özeş. İstanbul: Say Yayınları.

Dürüşken, Ç. (2020). Antikçă̆g Felsefesi. İstanbul: Alfa Yayınları.

Gökberk, M. (1998). Felsefe Tarihi. İstanbul: Remzi Kitabevi.

Guthrie, W. K. C. (2011). Yunan Felsefe Tarihi: Sokrates Öncesi Ilk Filozoflar ve Pythagorasçılar. Çev. Ergün Akça. İstanbul: Kabalcı Yayınları.

Jeager, W. (2011). Illk Yunan Filozoflarında Tanrı Düşüncesi. Çev. Güneş Ayas. İstanbul: İthaki Yayınları

Hadot, P. (2012). Ruhani Alıştırmalar ve Antik Felsefe. Çev. Kübra Gürkan. İstanbul: Pinhan Yayıncilık.

Herakleitos. (2005). Fragmanlar. Çev. Cengiz Çakmak. İstanbul: Kabalıı Yayınları.

Herakleitos. (2016). Fragmanlar. Çev. Arzu Akgün. İstanbul: Kabalcı Yayınları.

Herakleitos. (2019). Fragmanlar. Çev. Güvenç Şar, Erdal Yıldız. İstanbul: Dergâh Yayınları.

Herakleitos. (2020). Fragmanlar. Çev. C. Cengiz Çevik. İstanbul: Türkiye İş Bankası Kültür Yayınları.

Ferry, L. (2018). Gençler İçin Batı Felsefesi. Çev. Devrim Çetinkasap. İstanbul: Türkiye İş Bankası Kültür Yayınları.

Heil, J. (2020). Zihin Felsefesi, Çă̆daş Bir Giriş. Çev. Seda Akbıyık, Merve Bilgili. İstanbul: Küre Yayınları.

Kranz, W. (2014). Antik Felsefe Metinler ve Açılamalar. Çev. Suat Y. Baydur. İstanbul: Cinius Sosyal Yayınlar

Mandik, P. (2014). This is Philosophy of Mind, An Introduction. Wiley Blackwell.

Onur, F. (2019). “Bilinç Problemi ve Panpsişizm." MetaZihin: Yapay Zeka ve Zihin Felsefesi Dergisi, 2(1): 67-91. Alındığı URL: https://dergipark.org.tr/tr/pub/metazihin/issue/46637/548944

Priest, S. (2018). Zihin Üzerine Teoriler. Çev. Ayhan Dereko. İstanbul: Litera Yayıncllık. 
Revonsuo, A. (2016). Bilinç, Öznelliğin Bilimi. Çev. Selim Değirmenci. İstanbul: Küre Yayınları.

Skirberg, G. ve Gilje, N. (2014). Antik Yunan'dan Modern Dönem'e Felsefe Tarihi. Çev. Emrah Akbaş, Şule Mutlu. İstanbul: Kesit Yayınları.

Solomon, R. C. ve Higgins, K. M. (2013). Felsefenin Kısa Tarihi. Çev. Mustafa Topal. İstanbul: İletişim Yayınları. 